\title{
Respon Komunitas Istri terhadap Bimbingan Agama
}

\author{
Mela Purnama \\ Jurusan Bimbingan dan Konseling Islam, UIN Sunan Gunung Djati, Bandung \\ *Email : mela.purnama13@gmail.com
}

\begin{abstract}
ABSTRAK
Tulisan ini mengungkapkan tentang perhatian komunitas itri yang ditinggal suami melaut terhadap bimbingan agama, pemahaman komunitas istri yang ditinggal suami melaut terhadap bimbingan agama, penerimaan komunitas istri yang ditinggal suami melaut terhadap bimbingan agama. Metode yang digunakan dalam penelitian ini adalah metode deskriptif dengan menggunakan pendekatan kualitatif. Teknik pengumpulan data yang dilakukan melalui observasi, wawancara langsung dengan ketua Majelis ta lim Al-Muttaqin dan kepada jama'ah yang posisinya sebagai istri nelayan, menafsirkan data dan menarik kesimpulan serta dokumentasi. Hasil yang didapat dalam penelitian ini menunjukan bahwa respon komunitas istri terhadap bimbingan agama cukup baik, bisa dilihat dari memperhatikannya materi yang disampaikan oleh pembimbing, memahaminya materi yang disampaikan oleh pembimbing dan menerimanya materi yang disampaikan oleh pembimbing dengan cara mengaplikasikannya pada kehidupan sehari-hari.
\end{abstract}

Kata Kunci : Respon; Komunitas Istri; Bimbingan Agama.

\section{ABSTRACT}

In this research explains the care of wife community left by husband to go to the sea about their guidance of religion, the method used in this research is descriptive method by using qualitative approach. The technique of collecting data is done throughobservation, direct interview with the chairman of Al-Muttqin ta' 'im Council and to jama 'ah whose position as fisherman's wife, interpret the data and draw conclusions and documentation. The results obtained in this study indicate that the wife's community response to religious guidance is good enough, can be seen from the care of the material presented by the supervisor, understanding the material presented by the supervisor and receiving the material presented by the supervisor and receiving the 
material presented by the supervisor by applying it to everyday life.

Keywords : Response; Community Wife; Religious.

\section{PENDAHULUAN}

Pantai Pangandaran ditempati oleh para nelayan suku Sunda yang menjadi suku asli Jawa Barat. Para nelayan ini lebih memilih tinggal dan menetap di daerah Pangandaran dikarenakan pantai ini memiliki gelombang ombak yang cukup kecil jadi memudahkan untuk mencari ikan di laut. Kebanyakan para nelayan ini adalah pendatang dari luar daerah Galuh (sekarang Ciamis), biasanya para nelayan ini menyimpan perahu mereka disemenanjung (dataran yang menjorok ke laut) oleh karena itu banyak sekali pendatang yang mengunjungi Pangandaran ini dan menetap sampai akhirnya menjadi sebuah perkampungan.

Dusun Sanghiangkalang merupakan salah satu Dusun yang terdapat di Desa Batukaras Kecamatan Cijulang Kabupaten Pangandaran. Dusun ini sangat dekat dengan pantai Batukaras. Warga masyarakat Dusun Sanghiangkalang ratarata bekerja sebagai nelayan. Mereka menjadi nelayan itu karena memang lahir di sekitaran pantai, mereka juga terlahir dari orang tua yang pekerjaannya sebagai nelayan dankarena rata-rata pendidikannya kurang jadi mengharuskan mereka bekerja sebagai nelayan. Ketika sore hari menjelang para nelayan mempersiapkan peralatannya untuk pergi ka tengah lautan. Para istripun mengikutinya untuk sekedar mengantarkan suaminya naik perahu dan pergi ke tengah lautan. Seminggu kemudian ketika pagi menjelang para istri menunggu kepulangan suami di pinggir pantai, untuk menjeput pulang dan membantu mengeluarkan hasil tangkapan ikan dilautan. Karena banyaknya masyarakat yang bekerja sebagai nelayan, mereka membentuk satu komunitas yang bernama KUB (Kelompok Usaha Bersama).

Resiko besar yang harus dihadapi nelayan adalah terbatasnya waktu untuk berkumpul dengan keluarga. Terdapat konflik peran pada istri-istri yang suaminya memiliki waktu kerja yang panjang, karena dengan demikian kesempatan untuk membangun nilai-nilai keluarga seperti kedekatan, kehangatan, komunikasi dan pahala ibadah istri kepada suami menjadi berkurang. Banyak lagi kewajiban-kewajiban suami yang tidak terpenuhi seutuhnya karena terbatasnya waktu yang dimiliki karena tuntutan pekerjaannya. Kondisi dimana istri harus lebih banyak menanggung beban terhadap kelangsungan kehidupan rumah tangga seperti istri nelayan akan menyebabkan tidak dapat dipenuhinya beberapa faktor di atas.

Peran istri nelayan rela mengatasi segala sesuatu seorang diri dan ikhlas mengesampingkan perasaannya demi menjalani sebuah komitmen dan setia 
melaksanakan tugas sebagai seorang istri nelayan sebagaimana mestinya, meskipun intensitas pertemuan yang dapat dikatakan sangat kurang karena waktu pekerjaan lebih lama dibandingkan dengan waktu kebersamaan dalam sebuah keluarga di setiap harinya. Tak jarang para istri nelayan menjadikan diri mereka mengambil peran ganda sebagai istri dan orang tua dari anak-anaknya dalam hal kegiatan sehari-hari, seperti memenuhi kebutuhan sang anak, dan sederet daftar tunggu service pernak-pernik perlengkapan rumah tangga. Mau tidak mau mereka harus tegar, ikhlas, mengerti resiko yang dihadapi dan juga tak lupa terus berdoa untuk keselamatan suami dalam melaksanakan pekerjaannya.

Ketika suami tidak ada di rumah para istri selain mengurus pekerjaan rumah dengan sendiri, untuk mengisi waktu kosongnya sebagian istri nelayan ada yang menunggu warung dagangan, ada yang mengurus anaknya, ada juga yang hanya berkumpul di warung dengan ibu-ibu yang lain hanya sekedar untuk membicarakan hal-hal yang tidak begitu penting. Ada hal yang lebih bermanfaat yang mereka bisa lakukan, seperti didekat rumah mereka terdapat masjid yang sering melaksanakan kegiatan pengajian. Pengajian rutinan ini memiliki respon yang kurang dari ibu-ibu terlihat dari yang mengikuti pengajian hanya sebagian kecil. Padahal pemahaman keagamaan mereka itu tidak begitu banyak, apalagi mengenai Al-Qur`ah dan fiqih sehingga menyebabkan para istri kurang begitu paham mengenai keagamaan dan kurang tertarik untuk pergi ke pengajian tersebut. Ada beberapa faktor kemungkinan yang menyebabkan kurang tertariknya atas ketidakhadiran dalam pengajian, di antaranya: kesibukan ibu-ibu atau mad $u$ itu sendiri dan jadwal waktu pengajian yang kurang tepat yaitu pada hari jum `at pada pukul 08:00 sampai jam 11.

Kegiatan pengajian di Majelis ta lim tentu memiliki peran penting dalam peningkatan kualitas sumber daya manusia. Sebab, melalui penyampaian pesanpesan keislaman yang menjadi pokok kegiatannya, kegiatan pengajian di Majelis ta 'lim disamping dapat berfungsi sebagai mediator ia juga sesungguhnya dapat berfungsi sebagai wahana agar manusia yang terlibat dalam proses pembangunan kelak adalah manusia yang memiliki semangat, visi dan misi kemanusiaan yang tinggi serta memiliki petunjuk dan moralitas Islam yang baik. Selain itu, secara fungsional, ia juga dapat mengokohkan landasan hidup manusia, khususnya dalam bidang mental spiritual Islam dalam upaya meningkatkan kualitas hidupnya secara intergral, lahiriah dan batiniah, duniawi dan ukhrawi, sesuai dengan tuntunan ajaran Islam.

Majelis ta lim sangat membantu masyarakat untuk bisa lebih paham mengenai keagamaan. Majelis ta lim yang terdapat di daerah Sanghiangkalang dilaksanakan setiap satu minggu sekali tepatnya pada hari jum `at pada pukul 
08:00 sampai jam 11. Materi yang dibahas mengenai Al-Qur`an dan terjemah, tajwid, hadist, aqidah, akhlak dan bab rumah tangga (kitab uqudulujen). Metode yang digunakan adalah metode ceramah dan tanya jawab. Bahkan selain pengajian rutinan yang dilaksanakan di Dusun Sanghiangkalng adapula pengajian yang dilaksanakan di dusun lain, selain itu ada juga di Kecamatan biasa di sebut Gedung dak'wah. Dengan ini para istri nelayan bisa memanfaatkan kegiatan pengajian tersebut, melakukan kegiatan-kegiatan yang positif, bukan hanya berkumpul-kumpul diwarung dan membicarakan hal-hal yang tidak bermanfaat.

Hasil dari penulusuran yang dilakukan, terdapat penelitian terdahulu yang membahas mengenai Respon Ibu-Ibu Terhadap Bimbingan Keagamaan Bersama Hj. Ninih" yang mengungkapkan bahwa respon ibu-ibu Majelis ta 'lim Masjid AlMuhajirin terhadap bimbingan keagamaan cukup positif dilihat dari hasil perolehan yang berdasarkan pada tiga variabel penting. Pertama, mengenai perhatian jam`ah Majelis ta lim Al-Muhajirin terhadap bimbingan keagamaan memiliki skor $\mathrm{X}=2,65$ yang berada pada tingkat tinggi. Kedua, mengenai pemahaman ibu-ibu Majelis ta im Al-Muhajirin terhadap bimbingan keagamaan memiliki skor $\mathrm{X}=2,65$ yang berada pada tingkat tinggi. Ketiga, mengenai penerimaan ibu-ibu Majelis ta 'lim Masjid Al-Muhajirin terhadap bimbingan keagamaan memiliki skor $\mathrm{X}=2,73$ yang berada pada tingkat tinggi. Dengan demikian kesimpulan menunjukan bahwa bimbingan keagamaan mendapatkan respon positif dari ibu-ibu Majelis ta lim Masjid Al-Muhajirin. (Rizky Azhari Ramdhani: 2012).

Selain itu, terdapat penelitian terdahulu mengenai religiositas masyarakat pesisir (Ruslan, 2014). Hasil penelitian tersebut menunjukkan bahwa di dalam berinteraksi antarsesama, umumnya orang pesisir lebih menekankan substansi (sesuatu yang dikehendaki), bukan dengan cara mengekspresikan keinginan mengemasnya secara berputar-putar (teoritis) sehingga bimbingan agama yang disampaikan harus sesuai dengan karakteristiknya supaya apa yang disampaikan dapat sesuai dengan tujuan yang diharapkan. Adapun penelitian yang dilakukan oleh Inayah, Zanah \& Tajiri (2017) menunjukan bahwa kondisi keagamaan mayoritas beragama islam, kegiatan keagamaan yang ada yaitu pengajian mingguan, pengajian bulanan, sholat jum'at, sholat berjama'ah, tahlilan, aqiqahan, yasinan, dan memperingati hari-hari besar Islam, selain itu juga adanya syukuran para nelayan setiap tahun yang biasa disebut pesta laut atau kebudayaan leluhur (nadran) yang di sertai dengan ritual keagamaan.

Berdasarkan pemaparan latar belakang di atas, maka dapat membuat fokus penelitian sebagai berikut: bagaimana perhatian komunitas istri yang ditinggal 
suami melaut terhadap bimbingan agama? Bagaimana pemahaman komunitas istri yang ditinggal suami melaut terhadap bimbingan agama? Bagaimana penerimaankomunitas istri yang ditinggal suami melaut terhadap bimbingan agama?

Metode yang digunakan dalam penelitian ini adalah deskriptifkualitatif, dengan menganalisis hasil pengumpulan data melalui observasi dan wawancara dengan ketua Majelis ta lim Al-Muttaqin dan kepada jama`ah yang posisinya sebagai istri nelayan.

\section{LANDASAN TEORITIS}

Teori yang menjadi landasan penelitian ini adalah teori S-O-R (SitimulusOrganism-Respon) efek yang ditimbulkan adalah reaksi khusus sehingga seseorang dapat mengharapkan dan memperkirakan kesesuaian antara pesan dan reaksi komunikan (Onong, 2004: 254). Dari respon tersebut tentu komunikan akan mengalami perubahan positif atau negatif, perubahan ini disebut perubahan sikap. Dalam proses perubahan sikap tampak bahwa sikap dapat berubah hanya jika stimulus yang menerpa benar-benar melebihi semula.

Dengan demikian respon itu terjadi apabila ada stimulus yang diterima oleh komunikan, adapun kualitas respon tergantung kepada kuat dan lemahnya stimulus yang diberikan.

Brenan menyatakan demi efektifnya komunikasi perlu diperhatikan semua unsur yang terdapat dalam komunikasi, yaitu komunikator, komunikan, tujuan, peristiwa, metode, media, dan tanggapan atau respon. Formula yang disederhanakan akan merupakan paradigma yang lemah, bila tanggapan ditiadakan, artinya tanggapan (respon) merupakan hal pokok yang tidak dihilangkan (Onong, 2004: 27).

Respon dalam komunikan akan ditemukan pada bentuk komunikasi dua arah, dimana komuinikan mempunyai ruang dan kesempatan yang terbuka untuk menyampaikan tanggapan atau responnya terhadap komunikator.

Dalam situasi komunikasi massa, umpan balik umumnya bersifat tidak langsung atau delayed atau indirect, yaitu dalam bentuk diterima atau tidak diterima, diperhatikan atau tidaknya bimbingan agama tersebut olah para jama ah dan sebagainya. Onong Uchjana Effendi (1993: 40) mengungkapkan tentang pentingnya konsep respon dengan istilah umpan balik, komunikator akan mengetahui tingkat keberhasilan komunikasi yang dilakukannya. Dengan kata lain, ia dapat mengetahui efek atau akibat dari komunikasi yang dilancarkannya itu, apakah positif atau negatif. 
Respon dalam pelaksanaan bimbingan agama menandakan bahwa bimbingan agama dalam pelaksanaannya berjalan dua arah. Respon yang diberikan objek atau (jama`ah) sangat penting bagi perbaikan dan peningkatan kualitas bimbingan agama selanjutnya, karena pembimbing merasa dievaluasi dan diperhatikan. Karena itu, secara psikologis pembimbing harus merasa terdorong untuk meningkatkan kualitas bimbingan agamanya.

Sedangkan menurut Muhammad Surya (dalam Ahmad Tafsir, 2012: 121) yaitu: Bimbingan merupakan suatu proses pemberian bantuan yang terus menerus dan sistematis dari pembimbing kepada yang dibimbing agar tercapai kemandirian dalam pemahaman diri, pengarahan diri, dan perwujudan diri dalam mencapai tingkat perkembangan yang optimal dan penyesuaian diri dengan lingkungnya.

Agama menurut M. Arifin (1994: 1) terdiri dari dua aspek, yaitu: pertama, Aspek subjektif (pribadi manusia). Agama mengandung perhatian tentang tingkah laku manusia, yang dijiwai oleh nilai-nilai keagamaan, berupa getaran batin, yang dapat mengatur, dan mengarahkan tingkah laku tersebut, kepada pola hubungan dengan masyarakat, serta alam sekitarnya. Dari aspek inilah manusia dengan tingkah lakunya itu, merupakan perwujudan dari "pola hidup" yang telah membudaya dalam batinnya, dimana nilai-nilai keagamaan telah membentuknya menjadi rujukan (referensi) dari sikap, dan orientasi hidup sehari-hari. Kedua, Aspek objektif (doktrinair). Agama dalam pengertian ini mengandung nilai-nilai ajaran Tuhan yang bersifat menuntun manusia ke arah tujuan yang sesuai dengan kehendak ajaran tersebut. Agama dalam pengertian ini belum masuk ke dalam batin manusia, atau belum membudaya dalam tingkah laku manusia, karena masih bersifat doktrin (ajaran) yang objektif berada diluar diri manusia. Oleh karena itu, secara formal, agama dilihat dari aspek objek dapat diartikan sebagai "peraturan yang bersifat lillah (dari Tuhan) yang menuntun orang-orang berakal budi ke arah ikhtiar untuk mencapai kesejahteraan hidup di dunia, dan memperoleh kebahagiaan hidup di duni dan akhirat".

Melihat pengertian agama di atas, maka dapat disimpulkan bahwa agama merupakan pandangan pegangan hidup umat manusia menuju jalan yang tegak, lurus dan sesuai dengan fitrah manusia, yang dapat petunjuk atau tuntunan agar kehidupan uamat manusia teratur dan tidak hancur.

Dengan demikian, maka bimbingan agama dapat diartikan sebagai "usaha pemberian bantuan kepada seseorang yang mengalami kesulitan, baik lahiriah maupun batiniah, yang menyangkut kehidupan di masa kini dan masa mendatang. Bantuan tersebut berupa pertolongan dibidang mental spiritual. Dengan maksud agar orang yang bersangkutan mampu mengatasi kesulitannya 
dengan kemampuan yang ada pada dirinya sendiri, melalui dorongan dari kekuatan iman, dan takwa kepada Tuhan Yang Maha Esa. Oleh karena itu, sasaran bimbingan agama adalah membangkitkan daya rohaniah manusia melalui iman, dan ketakwaan kepada Allah SWT.

Bimbingan agama sebagai bagian dari dimensi kerisalahan dakwah merupakan kegiatan yang wajib dilakukan sebagaimana adanya kewajiban berdakwah. Dalam hal ini pendapat Aep Kusnawan (2009: 17) bahwa dakwah kerisalahan dalam prakteknya merupakan proses mengkomunikasikan dan menginternalisasikan nilai-nilai Islam. banyak pendapat tentang pengertian bimbingan agama. Salah satunya mengutip pendapat Samsul Munir Amin (2010: 23) tentang bimbingan agama konseling Islam terlepas dari adanya kata konseling bahwa,

'Bimbingan agama adalah proses pemberian bantuan terarah, kontinu dan sistematis kepada setiap indvidu agar ia dapat mengembangkan potensi atau fitrah dengan cara menginternalisasikan nilai-nilai yang terkandung didalam Al-Qur’an dan hadist Rasulullah Saw kedalam dirinya, sehingga ia dapat hidup selaras dan sesuai dengan tuntutan Al-Qur`an dan hadist”.

Secara spesifik, tujuan bimbingan agama yang dikemukakan oleh Samsul Munir Amin bahwa bimbingan agama bertujuan agar individu memiliki sumber pegangan agama dalam pemecahan problem dan membantu individu agar secara sadar dengan kemauannya mengamalkan ajaran agama.

Dalam Agama Islam, bimbingan agama merupakan bagian dari kegiatan dakwah Islam. Dalam suatu kegiatan tentu terdapat unsur-unsur didalamnya, adapun unsur-unsur dari bimbingan agama dalam buku Lilis satriah (2015: 84) terdiri dari hal-hal sebagai berikut: Materi dakwah, yaitu ajaran Islam yang bersumber dari Al-Qur`an, Assunah maupun hasil-hasil ijma ulama, Da`i (Mubaligh), yaitu orang-orang yang menyampaikan dakwah, Mad $u$, yaitu objek atau sasaran dakwah, Metode, yaitu cara menyampaikan dakwah, Media, yaitu sarana untuk menyampaikan dakwah,dan Tujuan dakwah.

Sedangkan menurut pendapat dari sumber lain dilihat dari segi telaah ontologis dakwah Islam dapat diartikan sebagai perilaku keberagamaan Islam berupa proses internalisasi, transmisi, difusi dan transformasi ajaran Islam yang melibatkan unsur subjek (da'i), pesan (mawdhu'), metode (ushlub), media (washilah) dan objek (mad'u) yang berlangsung dalam rentang ruang dan waktu untuk mewujudkan kehidupan individu dan kelompok yang salâm, hasanah, thayyibah dan memperoleh ridha Allah.

Sedangkan disiplin ilmu dakwah adalah sistem penjelasan objektif proporsional (POP) perilaku kebergamaan Islam berupa irsyad, tabligh, tadbir, 
tamkin/tathwir Islam yang melibatkan unsur subjek, objek, pesan, metode, dan media dalam situasi-kondisi tertentu guna menegakkan tawhidullah, keadilan dan mensolusi problema kehidupan umat manusia. Penyebutan istilah disiplin ilmu dakwah ini secara epistemologis harus ada, dalam rangka memberikan kerangka acuan teoritis dari hakikat dakwah itu sendiri untuk melahirkan berbagai sub disiplin ilmu dakwah (Arifin, 2008: 29).

\section{HASIL DAN PEMBAHASAN}

Majelis ta lim Al-Muttaqin terletak di RT.04/RW.02 Dusun Sanghiangkalang Desa Batukaras Kabupaten Pangandaran. Majelis ta lim ini terletak di tengahtengah pemukiman penduduk.

\begin{tabular}{lc}
\multicolumn{2}{c}{ Tabel 1. Jenis Kelamin Jama`ah } \\
\hline Jenis kelamin & Jumlah \\
\hline Laki-laki & 0 \\
Perempuan & 60 \\
\hline
\end{tabular}

Sumber : Hasil Observasi dan Wawancara (Ibu Nurhasanah, 15 Desember 2017)

Tabel di atas menunjukan jumlah jama ah dari perbedaan jenis kelamin pada tabel tersebut tampak jumlah jama ah laki-laki tidak ada. Sedangkan jumlah jama`ah perempuan lebih banyak. Hal ini menunjukan bahwa kaum perempuan lebih aktif dalam mengikuti pengajian di Majelis ta'lim Al-Muttaqin. Kesenjangan tersebut bisa jadi disebabkan oleh kegiatan kaum laki-laki yang lebih mendominasi, baik itu pekerjaan ataupun hal lainnya bahkan sampai pada minimnya kesadaran keagamaan. Lain halnya dengan kaum perempuan disamping lebih respek terhadap pengajian ini mereka lebih memiliki waktu luang.

\begin{tabular}{ccc}
\multicolumn{2}{c}{ Tabel 2. Usia Jama ah Majelis Ta ${ }^{\text {Usia }}$} & Jim Al-Muttaqin \\
\hline $24-28$ & & Jumlah \\
$29-33$ & 5 & \\
$34-38$ & 7 & \\
\hline
\end{tabular}




\begin{tabular}{ll}
\hline $39-43$ & 3 \\
$44-48$ & 8 \\
$49-53$ & 7 \\
$54-58$ & 12 \\
$59-63$ & 10 \\
$64-68$ & 4 \\
Jumlah & 60 \\
\hline
\end{tabular}

Sumber : Hasil Observasi dan Wawancara (ibu Nurhasanah, 15 Desember 2017)

Tabel di atas memperlihatkan variasi usia jama`ah Majelis ta`lim AlMuttaqin. Fenomena di atas menarik mengingat selama ini pengajian-pengajian banyak dihadiri oleh para orang tua

Tabel 3. Pendidikan Jama`ah Majelis Ta lim Al-Muttaqin

\begin{tabular}{|c|c|}
\hline Tingkat Pendidikan & Jumlah \\
\hline S1 & 2 \\
\hline SLTA & 30 \\
\hline SLTP & 18 \\
\hline SD & 10 \\
\hline Jumlah & 60 \\
\hline
\end{tabular}

Sumber : Hasil Observasi dan Wawancara (ibu Nurhasanah, 15 Desember 2017)

Tabel di atas memperlihatkan variasi latar belakang jama`ah Mejelis ta `lim Al-Mutaqin. Fenomena di atas dapat dikatakan bahwa mayoritas jama`ah Majelis ta lim Al-Muttaqin pendidikannya tinggi. Ini berarti tingkat intelektualitas jama`ah tersebut dapat dikatakan pada umumnya. Dilihat dari status pernikahan, jama`ah yang berstatus belum menikah tidak ada. Dari fenomena di atas dikatakan jama`ah Majelis ta`lim Al-Muttaqin berstatus menikah. Hal ini disebabkan karena orang yang sudah menikah memiliki waktu luang lebih banyak kegiatan, baik kegiatan yang menyangkut pekerjaan, persoalan rumah tangga dan waktu luang untuk mengikuti pengajian.

Bimbingan agama yang dilaksanakan di Majelis ta lim Al-Muttaqin yaitu 
suatu proses pemberian bantuan kepada jama`ah agar jama`ah bisa memiliki dan mengembangkan situasi dan kondisi yang tidak baik menjadi baik dan kondisi yang baik menjadi lebih baik.

Proses bimbingan agama di Majelis ta lim Al-Muttaqin dilaksanakan satu minggu sekali tepatnya hari jum ’at pada jam 08:00 sampai jam 11:00. Adapun proses rangkaian bimbingan agama pertama pembacaan ayat suci Al-Qur’an, pembacaan ayat suci Al-Qur'an dilakukan secara bergiliran, setelah selesai pembacaan ayat suci Al-Qur`an, kedua dilanjutkan dengan pembacaan tawasul di bacakan secara bersamaan. Setelah selesai pembacaan ayat suci Al-Qur`an dan tawasul baru dilaksanakannya ceramah atau pemberian materi.

Pelaksanaan bimbingan agama akan berjalan dengan baik jika terlaksananya unsur-unsur bimbingan, di antaranya: Pembimbing yang terlibat dalam kegiatan ini terdiri dari ustad dan ustadah pelaku dakwah yang mempunyai tanggung jawab terhadap umat juga mempunyai komitmen untuk ikut memajukan khazanah keilmuan. Berwawasan luas dan sangat ingin memajukan umat dalam bidang keagamaan, tentunya hal ini menjadi sebuah tantangan tersendiri dan tetap bisa terlaksana sesuai dengan program yang telah direncanakan. Mengingat didalam bimbingan (irsyad) terkandung aspek mempengaruhi orang lain, maka seorang pembimbing harus memenuhi karakteristik yang dilihat dari sifat nafsiyah, yaitu kepemilikan suasana kepribadian yang sempurna baik batin maupun lahir yang mencerminkan sikap dan perilaku keislaman, sifat jasadiyah yaitu kepemilikan kondisi badan yang sehat dari berbagai penyakit jasmaniyah yang membuat orang lain menjauhkan diri dari pergaulan dengan dirinya. Dan yang terakhir yaitu sifat ijtimaiyah yaitu kepemilikan kesempurnaan perilaku dalam interaksi dengan orang lain sebagai anggota masyarakat (Enjang dan Mujib, 2013: 73).Majelis ta lim Al-Muttaqin memiliki beberapa ustad dan ustadah (pembimbing). Dengan latar belakang pendidikan yang hanya sampai tingkat SLTA dan tingkat SLTP kemudian dilanjutkan dengan pendidikan non formal yaitu pesantren, akan tetapi tingkat keilmuan dan pengalaman mereka sudah tidak diragukan lagi. Bisa dibuktikan dengan mereka mampu mengajak jama'ah untuk selalu konsisten dalam mengikuti pengajian. Selain mampu mengajak, mereka juga mampu memberikan pemahaman mengenai keagamaan terhadap jama’ah yang masih awam dalam masalah keagamaan.

Jama`ah dalam proses bimbingan agama berperan sebagai orang yang membutuhkan bimbingan. Jama`ah yang datang ke Majelis ta lim Al-Muttaqin ini tidak hanya dari warga masyarakat Dusun sekitar adapula dari Dusun-dusun yang lain. Adapun pendatang dari luar Jawa Barat yang sudah menetap di Dusun 
Sanghiangkalan dan mereka ikut bergabung mengikuti pengajian tersebut. Selain itu jama ah yang datang ke Majelis ta lim Al-Muttaqin ini berasal dari latar belakang yang berbeda, dari segi pendidikan kebanyakan jama`ah Majelis ta`lim Al-Muttaqin hanya sampai tingkat SLTA dan tingkat SLTP bahkan ada yang sampai tingkat SD, bisa dihitung dengan jari yang datang ke Majelis Ta 'lim ini yang pendidikannya sampai tingkat S1. Kemudian dari segi perekonomian, kebanyakan masyarakat Dusun Sanghiangkalang bekerja sebagai nelayan, begitupun dengan jama`ah yang datang ke Majelis ta`lim Al-Muttaqin di dominasi dengan ibu-ibu yang suaminya itu bekerja sebagai nelayan. Sesuai dengan sasaran penulis yaitu ibu-ibu yang ditinggal suaminya melaut, mereka datang ke pengajian tersebut ketika mereka memiliki waktu kosong saja. Alasan mereka tidak mengikuti pengajian karena banyaknya kegiatan rumah tangga yang harus dijalaninya dengan sendirian lalu kurangnya dorongan dari suami.

Materi yang di sampaikan di Majelis ta lim Al-Muttaqin disesuaikan dengan kondisi dan kebutuhan jama ah. Adapun materi yang disampaikan terdiri dari lima materi yaitu: Pertama, materi yang disampaikan adalah al-qur an dan terjemah, tajwid, materi ini membahas tentang bagaimana tata cara membaca alqur an dengan baik dan benar sesuai dengan tajwid, menjelaskan isi kandung ayat yang sedang dibahas. Kedua, materi yang dibahas adalah aqidah, aqidah sangat perlu disampaikan kepada jama`ah agar jama`ah mampu memahami perkaraperkara yang berkaitan dengan keyakinan terhadap Allah Swt dan sifat-sifat kesempurnaan-Nya. Ketiga, al-hadits inti ajaran Islam dibangun di atas dua pondasi: Al-Qur'an dan Sunnah. Keduanya memiliki kaitan yang sangat erat. Banyak ayat-ayat Al-Qur'an yang tidak bisa diartikan dengan benar dan tepat tanpa bantuan keterangan dari Sunnah Nabi Saw. Keempat, materi yang disampaikan adalah akhlak, akhlak merupakan pondasi yang kokoh bagi terciptanya hubungan baik antara hamba dengan Allah Swt (hablumminallab) dan antara sesama (hablumminannas). Akhlak yang mulia (akhlakul karimab) tidak lahir begitu saja sebagai kodrat manusia, atau terjadi secara tiba-tiba. Akan tetapi, membutuhkan proses panjang serta manifestasi seumur hidup melalui pembelajaran atau pendidikan. Kelima, materi yang dibahas adalah bab rumah tangga dari kitab uqudulujain. Dengan mempelajari kitab tersebut jama ah bisa mengetahu perkara apa saja yang harus dilakukan dan tidak boleh dilakukan dalam rumah tangga.

Media dakwah instrumen yang dilalui oleh pesan atau saluran pesan yang menghubungkan antara da ${ }^{\prime}$ dan mad ’u. Media yang digunakan di Majelis Ta lim Al-Muttaqin dalam proses bimbingan agama ini hanya merupakan bahan atau alat pendukung demi kelancaran kegiatan berlangsung seperti meja, kursi dan 
mix.

Respon merupakan suatu hal yang selalu ada dalam proses dakwah ataupun bimbingan agama. Dengan adanya respon pada pelaksanaan bimbingan agama di Majelis ta 'lim, berarti bmbingan agama tersebut memang ditanggapi oleh jama`ah. Respon di majelis ta lim didalamya mencakupi respon sanggahan dan bahasa non verbal. Untuk mengetahui lebih jelasnya tentang respon dari komunitas istri (jama'ah) diperlukan sebuah pembatasan dan batasan. Hal tersebut bisa dilihat pada teori S-O-R yang di dalam teori itu terdapat tiga aspek respon yaitu: perhatian, pemahaman dan penerimaan. Karena dalam kegiatan bimbingan agama di majelis ta`lim didalamnya mencakup sebuah pernyataan yang bersifat positif dan negatif.

Jadi diterima atau tidaknya proses bimbingan agama di majelis ta`lim tersebut, bisa dijadikan sebuah acuan dalam proses bimbingan agama selanjutnya. Demikian pula halnya dengan respon komunitas istri terhadap bimbingan agama di majelis ta lim Al-Muttaqin dapat dijadikan sebagai acuan bagi proses kegiatan bimbingan agama di masa yang akan datang.

Untuk mengetahui kegiatan bimbingan agama di Majelis ta lim ini dilakukan penganalisisan terhadap respon sanggahan dari materi yang disampaikan oleh pembimbing, hasil observasi pada tanggal 23 Februari 2018. Lebih jelasnya berikut adalah pemaparan tentang respon komunitas istri yang dilihat dari ketiga aspek yaitu perhatian, pemahaman dan penerimaan.

Dalam teori S-O-R stimulus atau materi yang disampaikan kepada komunikan mungkin diterima atau mungkin ditolak. Komunikasi akan berlangsung jika ada perhatian dari komunikan. Proses berikutnya komunikan mengerti. Kemampuan komunikan inilah yang melanjutkan proses berikutnya. Setelah komunikan mengolahnya dan menerimanya, maka terjadilah kesediaan untuk mengubah sikap. Penjelasan tersebut berkaitan dengan tiga aspek yang telah disebutkan di atas yaitu: perhatian, pemahaman dan penerimaan (Effendi, 1993: 255).

\section{Perhatian Komunitas Istri Yang Ditinggal Suami Melaut Terhadap Bimbingan Agama}

Pada bagian ini peneliti akan menguraikan perhatian komunitas istri yang ditinggal suami melaut terhadap bimbingan agama. Perhatian berarti adanya stimulus yang disampaikan pada suatu objek yang menyita waktu serta fokus objek tersebut. Perhatian jama`ah dalam proses bimbingan agama merupakan salah satu bentuk timbal balik (respon) jama`ah terhadap materi yang disampaikan oleh pembimbing. Bentuk perhatian dalam hal ini, jama`ah mampu 
mengalihkan segala bentuk perhatian yang mengganggu dirinya pada proses bimbingan agama yang dilakukan dengan pembimbing, sehingga dapat fokus perhatiannya terhadap materi yang disampaikan.

Perwujudan yang terjadi dari perhatian pada saat proses bimbingan agama oleh jama`ah menurut Nurhasanah (pembimbing) ditandai dengan adanya tatapan mata, menganggukan kepala, menerima materi yang disampaikan serta adanya timbal balik dari materi yang disampaikan pembimbing kepada dirinya. Dengan adanya respon dari jama ah dalam bentuk perhatian yang disampaikan oleh pembimbing, dapat menggambarkan perhatian jama`ah pada proses bimbingan agama.

Sedangkan dari segi bentuknya menurut Onong Uchjana Effendy (1997: 14) perhatian merupakan umpan balik yang disampaikan oleh atau datang dari komunikan. Atau dengan kata lain adalah umpan balik yang datang dari luar komunikator. Contohnya: komunikan yang menggunakan kepala berarti ia mengerti terhadap pesan yang disampaikan.

Seorang jamàah yang menganggukan kepala serta adanya umpan balik (respon) dari setiap kata-kata yang disampaikan pembimbing pada saat proses bimbingan agama menandakan bahwa adanya perhatian mengenai materi yang disampaikan oleh pembimbing, baik penjelasan secara lisan (verbal) maupun bahasa tubuh (non verbal). Dengan bentuk umpan balik (respon) jama ah dalam bimbingan agama dapat mempermudah pembimbing untuk menjadi pusat perhatian.

Adanya umpan balik yang positif yang ditunjukan tentu saja adanya komunikasi yang efektif yang dilakukan oleh seorang pembimbing dalam pemberian materi ketika proses bimbingan agama, baik secara lisan (verbal) dengan kata-kata yang membuat jama`ah merasa nyaman dan aman. Kemudian komunikasi bahasa tubuh (non verbal) yang dapat meyakinkan jama`ah untuk berusaha fokus terhadap materi yang disampaikan.

Perhatian jama ah yang baik saat melakukan bimbingan agama merupakan kesuksesan seorang pembimbing dalam proses bimbingan agama. Perhatian dimaknai dengan peralihan segala bentuk gangguan yang ditimbulkan oleh lingkungan eksternal jama`ah sehingga jama`ah dapat memfokuskan dirinya kepada pembimbing. Upaya pembimbing dalam mengambil perhatian jama ah dapat berupa dorongan atau motivasi saat melakukan bimbingan agama, hal ini dapat tergambar pada proses bimbingan agama seorang pembimbing berusaha meyakinkan jama`ah melalui keaktifan bertanya mengenai materi yang disampaikan. Pada dasarnya dalam pengambilan perhatian jama`ah yang dilakukan ibu Nurhasanah menerapkan metode ceramah dan tanya jawab yang 
tidak monoton dengan diselingi guyonan dan mengarahkan perhatian jama ah pada materi yang sedang disampaikan. Setelah jama`ah merasa tenang dan perhatiannya fokus terhadap ibu Nurhasanah, maka pada saat itu ibu Nurhasanah menyampaikan materi inti.

Dengan adanya perhatian dari jama’ah seorang pembimbing mampu memberikan penerangan-penerangan terhadap permasalahan jama`ah. Adanya perhatian seorang jama`ah dapat dimanfaatkan dengan sebaik-baiknya oleh pembimbing sehingga jama`ah mampu menyelesaikan permasalahannya. Kemudian ketika jama`ah memperhatikan pada materi yang disampaikan, proses bimbingan agama terasa nyaman dan tertib sehingga dapat berpengaruh kepada keberhasilan bimbingan agama.

Dengan demikian pada proses bimbingan agama yang dilakukan oleh ibu Nurhasanah bahwa adanya perhatian yang positif baik secara (lisan) verbal maupun bahasa tubuh (non verbal) yang ditunjukan oleh jama`ah melalui anggukan kepala, tatapan mata saat proses bimbingan, dan menerima materi yang disampaikan dari awal sampai akhir.

Maka pernyataan di atas diperkuat dengan penjelasan perhatian di bab II menyatakan bahwa proses mental ketika stimuli menjadi menonjol dalam keadaan saat stimuli lainnya melemah, perhatian terjadi apabila kita mengkonsentrasikan diri kita pada salah satu alat indra kita, dan mengesampingkan masukan-masukan alat indra lain (Jalaludin Rakhmat, 2003: 52).

\section{Pemahaman Komunitas Istri Yang Ditinggal Suami Melaut Terhadap Bimbingan Agama}

Pada bagian selanjutnya peneliti akan menguraikan hasil penelitian mengenai pemahaman jama ah terhadap materi yang disampaikan oleh pembimbing. Materi yang efektif yang dilakukan oleh seorang pembimbing dalam proses bimbingan agama merupakan faktor yang menentukan berjalan atau tidaknya suatu pemberian bimbingan agama. Apabila pemberian materi yang diberikan oleh pembimbing berjalan dengan baik, maka akan merubah suasana bimbingan agama menjadi hangat dan penuh dengan keakraban. Dari suasana yang hangat akan menimbulka umpan balik atas materi yang disampaikan oleh seorang pembimbing. Suasana yang akrab saat berkomunikasi antara pembimbing dan jama`ah akan menimbulkan keterbukaan serta keleluasaan jama`ah dalam menanyakan segala persoalan yang sedang dialami oleh jama`ah.

Berdasarkan penuturan ibu Nurhasanah mengenai komunikasi dirinya dengan jama`ah begitu hangat dan akrab ditunjukan dengan pembicaraan yang 
bekesinambungan dengan keterbukaan tentang permasalahan yang dialami oleh jama ah. Keterbukaan pada diri jama ah sudah tentu adanya pemahaman tentang permasalahan yang dihadapi dirinya maupun tentang materi yang disampaikan oleh ibu Nurhasanah.

Pemahaman dalam proses bimbingan agama sudah tentu jama`ah mampu menangkap makna dari materi yang disampaikan oleh pembimbing baik secara lisan (verbal) maupun bahasa tubuh (non verbal). Pemahaman jama ah dapat melancarkan proses bimbingan agama, maksudnya dengan pemahaman jama ah terhadap permasalahan yang dihadapinya akan lebih memahami arah dari pembicaraan serta bagaimana proses penyelesaian permasalahan yang dihadapi dirinya.

Pemahaman jama ah terhadap materi yang disampaikan akan menetukan arah bimbingan berlangsung, berangkat dari pemahaman mengenai materi yang ditranformasikan kepada jama ah akan ditimbulkan kesepahaman atau satu visi mengenai tujuan bimbingan agama dilaksanakan. Pemahaman yang ditangkap jama ah melalui komunikasi pembimbing dapat bersifat positf ataupun negatif. Pemahaman yang positif seorang jama ah mampu menangkap makna materi yang dimaksud oleh pembimbing mengenai permasalahannya. Sedangkan pemahaman yang negatif jama ah tidak mampu memahami makna materi yang disampaikan sehingga terjadi kesalah pahaman antara keduanya. Hal tersebut terjadi karena jama ah yang dihadapi beragam dengan berlatar belakang yang berbeda.

Dilihat dari ragamnya jama ah terdiri dari berbagai ragam yang dibentuk oleh berbagai latar belakang dan permasalahan yang berbeda. Secara umum jama`ah datang ke Majelis ta lim karena satu atau beberapa alasan, di antaranya: atas kemauan sendiri, kemauan atau anjuran keluarga dan ibu-ibu jama'ah lainnya. Apapun alasannya jama`ah mendatangi Majelis ta`lim, jama`ah sebenarnya sudah mengupayakan untuk mengatasi persoalan pribadi tanpa bantuan orang lain, atas bantuan orang lain, atas bantuan professional lain.

Sedangkan dilihat dari faktor lingkungannya jama`ah, menurut Parmin (2012: 12) menjelaskan sebagai berikut: Jenis Kelamin, Keluarga, Kebudayaan, Status sosial, Daerah, Keturunan.

Pengaruh lingkungan terhadap pribadi konseli (jama`ah), karena itu perlu sekali diperhatikan, Ivey, et al (1987: 40) mengemukakan bahwa: konseli (jama `ah) yang mendatangi Majelis ta lim adalah pada pertamanya, pada akhirnya dan selamanya adalah pribadi, namun setiap pribadi harus dilihat dalam hubungannya dengan lingkungan yang khusus.

Ragam jama ah yang dihadapi oleh ibu Nurhasanah berbeda karakter dan 
pemikiran berbeda mengenai persoalan pribadi yang dihadapinya. Ragam jama ah yang melakukan bimbingan agama yang disebutkan di atas serta dengan persoalan pribadi yang dihadapinya. Terkadang dengan kondisi jama ah seperti itu ibu Nurhasanah merasa kesulitas dalam proses penyelesaiannya tidak jarang ibu Nurhasanah merasa kesulitan dalam proses penyelesaian masalahnya. Dalam proses penyelesaiannya tidak jarang ibu Nurhasanah melibatkan pihak ketiga dalam proses penyelesaian masalahnya yaitu pembimbing yang lain.

Pemahaman jama ah terhadap materi yang disampaikan tidak terlepas dari keterampilan pembimbing dalam proses penyampaian materi. Keterampilan penyampaian materi yang dimiliki pembimbing dapat berpengaruh besar terhadap keberjalanan bimbingan agama. Pada dasarnya pembimbing mampu berkomunikasi yang efektif sehingga materi yang disampaikan tampak jelas dan tergambar dibenak jama`ah. Hal tersebut dilakukan agar tidak terjadi kesalah pahaman tentang penafsiran makna oleh jama`ah. Apabila pembimbing tidak mampu berkomnikasi secara efektif akan menimbulkan permasalahanpermasalahn baru dalam proses bimbingan agama sehingga permasalahan yang ada akan menjadi berkembang dan tidak terselesaikan.

Pemahaman jama`ah terhadap materi yang disampaikan oleh ibu Nurhasanah dapat berupa pertanyaan langsung mengenai persoalan pribadi yang sedang dihadapi, meminta penjelasan ulang mengenai materi yang disampaikan, memberikan sanggahan atas makna dari materi yang telah disampaikan, dan jama`ah dapat menyimpulkan persoalan yang sedang dihadapinya berdasarkan penerangan dari pembimbing. Sedangkan menurut penuturan dari jama ah yang bernama ibu Esih dan ibu Wida setelah melakukan bimbingan agama, bahwa penyampaian materi yang disampaikan oleh ibu Nurhasanah saat melakukan bimbingan agama begitu akrab dan hangat sehingga dalam melakukan bimbingan agama tidak ada perasaan canggung dan tidak ada perasaan tertekan. Hal ini terjadi disebabkan karena pendekatan saat berkomunikasi atau penyampaian materi yang di sampaikan oleh ibu Nurhasanah begitu sopan penuh dengan sapaan serta adanya perhatian yang berlebih terhadap persoalan yang sedang dihadapi. Kemudian dukungan dan dorongan yang dipacu oleh ibu Nurhasanah kepada jama ah begitu besar sehingga adanya semangat serta keinginan yang kuat untuk mengikuti pengajian secara rutin.

Pemahaman yang dibangun terhadap materi dalam rangka untuk menjalani kehidupan atas semua persoalan merupakan faktor penting yang harus dimiliki oleh jama`ah. Pemahaman dimaksud agar jama`ah memahami betul persoalan yang terjadi pada dirinya serta materi yang disampaikan oleh pembimbing. Dengan hal ini jama`ah mampu menggambarkan persoalan yang dialami dirinya 
saat melakukan bimbingan agama.

Dengan demikian materi yang disampaikan oleh ibu Nurhasanah kepada jama`ah mendapat respon yang positif dengan ditunjukan adanya kesepahaman mengenai persoalannya serta makna atau inti materi yang disampaikan. Sedangkan pada proses bimbingan agama jama ah dapat mencerna segala bentuk komunikasi baik secara lisan (verbal) maupun bahasa tubuh (non verbal) sehingga penafsiran dari jama ah sesuai dengan yang dimaksud oleh jama`ah. Hal ini bisa diperjelas dengan pengertian atau pemahaman adalah sebagai pengaruh yang disebabkan adanya respon memberikan wawasan tentang kehidupan batiniah atau kehidupan psikis sendiri, sehingga bisa dijadikan pelajaran untuk proses pembentukan watak, dan kepribadian sendiri. (Kartini, 1997:10)

\section{Penerimaan Komunitas Istri Yang Ditinggal Suami Melaut Terhadap Bimbingan Agama}

Dalam penelitian yang dimaksud dengan penerimaan yaitu perubahan sikap untuk berubah menjadi lebih baik dari yang sebelumnya. Kategori dalam keinginan untuk berubah menjadi baik ini dibagi menjadi tiga, yaitu aqidah, ibadah, dan akhlak. Dilihat dari hasil wawancara dengan jama`ah Majelis ta lim Al-Muttaqin ada keinginan untuk terhindar dari aqidah yang menyimpang, semakin rajin beribadah, dan semakin baik akhlaknya. (a) Terhindar Dari Aqidah Yang Menyimpang: Jama ah yang ingin berubah menjadi lebih baik, yang berkaitan dengan aqidah bisa dilihat dari sikap jama`ah ketika mendengarkan pembimbing menyampaikan materi mengenai syirik. Seperti yang diungkapkan oleh ibu Esih:

'Iya, ibu menyadari kekeliruan saat terlalu menuhankan kepada suatu benda, kemudian setelah mendengarkan dan mencoba memahami materi yang disampaikan oleh pembimbing ketika menyampaikan materi mengenai syirik, setelah itu ibu bisa membedakan antara adat dan agama” (wawancara tanggal 24 februari 2018). (b) Semakin Rajin Ibadahnya : Jama 'ah yang ingin berubah menjadi baik, yang berkaitan dengan ibadah bisa dilihat dari perilaku jama ‘h. Setelah mengikuti proses bimbingan agama jama`ah semakin rajin dalam mengikuti solat berjama`ah. Selain itu juga jam `ah setelah mengikuti bimbingan agama semakin termotivasi untuk membaca al-qur`an setiap harinya. Seperti yang diungkapkan oleh ibu Wida: 'Iya, setelah mengikuti bimbingan agama, ibu selalu ingin melakukan solat bejama ah di Masjid, karena sudah tau pahalanya solat berjama ah itu seperti apa, lalu Alhamdulillah setelah mengikuti bimbingan agama ini, ibu selalu ingin membaca ayat suci Al-Qur`an, karena sudah terbiasa ketika akan melakukan bimbingan agama selalu di awali dengan membaca AlQur`an jadi semakin terbiasa dan alhamdulillah juga setelah selesai sholat magrib 
ibu selalu meluangkan untuk membaca Al-Qur'an meskipun hanya beberapa ayat" (wawancara tanggal 24 februari 2018). (c) Semakin Baik Akhlaknya: Jama ah yang ingin berubah menjadi baik, yang berkaitan dengan akhlak bisa dilihat dari perilaku jama`ah. Setelah melakukan bimbingan agama, jama`ah dalam kehidupan sehari-hari menjadi lebih akrab dengan tetangga, lalu lebih sabar saat suami pergi dan bisa menjaga harta dari suami. Seperti yang diungkapkan oleh ibu Wati: "Awalnya ibu kurang begitu dekat dengan tetangga, karena di sekeliling rumah ibu ada beberapa orang baru, dan baru menetap di dekat lingkungan rumah ibu, akan tetapi waktu bimbingan agama, pembimbing pernah menjelasakn bahwa sesama orang muslim kita harus saling tolong menolong dan harus menjaga tali silaturahmi, nah ibu setelah mendengarkan perkataan itu, ibu langsung teringat dengan sikap ibu yang kurang begitu akrab dengan tetangga baru tersebut. Saat ini Alhamdulillah ibu dengan tetangga baru tersebut sudah mulai akrab seiring dengan berjalnnya waktu.

Kemudian ketika melakukan proses bimbingan agama, pembimbing pernah menerangkan hak dan kewajiban suami istri lalu istri solehah itu seperti apa, ibu menyadari betul bahwa pekerjaan suami ibu itu nelayan, yang hampir setiap harinya meninggalkan rumah. Akan tetapi setelah mendengarkan materi yang pernah disampaikan pembimbing ibu, bisa menerima pekerjaan suami dengan lapang dan mencoba untuk bersabar, menjaga harta suami dengan baik, dan Alhamdulillah sekarang sudah terbiasa di rumah tidak ada suami." (wawancara tanggal 24 februari 2018).

Dengan demikian penerimaan dapat dinyatakan dengan perubahan sikap dari keputusan yang menuju kepada tujuan sikap yang diharapkan. Berhasil atau tidaknya pesan yang disampaikan oleh komunikator dapat digolongkan dalam nilai tinggi, moderat, dan rendah (Mar`at, 1982: 32).

\section{PENUTUP}

Dari hasil penelitian berdasarkan fokus penelitian yang diajukan pada penelitian respon komunitas istri terhadap bimbingan agama dapat diambil simpulan sebagai berikut:

Pertama, Perhatian komunitas istri yang ditinggal suami melaut terhadap bimbingan agama dapat ditunjukan pada anggukan kepala, tatapan mata, dan menerima materi yang disampaikan oleh pembimbing pada saat proses bimbingan agama. Dengan demikian respon komunitas istri terhadap bimbingan agama dapat diketahui bahwa jama`ah merespon cukup baik terhadap bimbingan agama. 
Dengan adanya perhatian dari jama`ah seorang pembimbing mampu memberikan penerangan-penerangan terhadap permasalahan jama`ah. Adanya perhatian seorang jama`ah dapat dimanfaatkan dengan sebaik-baiknya oleh pembimbing sehingga jama`ah mampu menyelesaikan permasalahannya. Kemudian ketika jama`ah memperhatikan pada materi yang disampaikan, proses bimbingan agama terasa nyaman dan tertib sehingga dapat berpengaruh kepada keberhasilan bimbingan agama.

Kedua,Pemahaman jama`ah terhadap materi yang disampaikan tidak terlepas dari keterampilan pembimbing dalam proses penyampaian materi. Keterampilan penyampaian materi yang dimiliki pembimbing dapat berpengaruh besar terhadap keberjalanan bimbingan agama. Pada dasarnya pembimbing mampu berkomunikasi yang efektif sehingga materi yang disampaikan tampak jelas dan tergambar dibenak jama`ah. Hal tersebut dilakukan agar tidak terjadi kesalah pahaman tentang penafsiran makna oleh jama`ah. Apabila pembimbing tidak mampu berkomnikasi secara efektif akan menimbulkan permasalahanpermasalahn baru dalam proses bimbingan agama sehingga permasalahan yang ada akan menjadi berkembang dan tidak terselesaikan.

Pemahaman komunitas istri yang ditinggal suami melaut terhadap bimbingan agama dapat tergambar pada sanggahan jama`ah saat proses bimbingan agama, pemahaman inti materi yang disampaikan pembimbing, interpretasi bahasa lisan (verbal) dan bahasa tubuh (non verbal) pada diri pembimbing sehingga jama`ah dapat menerima inti materi yang disampaikan tanpa adanya kesalahan pahaman di antara keduanya.

Ketiga, Penerimaan jama`ah terhadap bimbingan agama dapat dilihat dari perubahan ke arah yang lebih baik lagi. 1) terhindar dari aqidah yang menyimpang, Jama ah yang ingin berubah menjadi lebih baik, yang berkaitan dengan aqidah bisa dilihat dari sikap jama ‘ah ketika mendengarkan pembimbing menyampaikan materi mengenai syirik; 2) semakin rajin ibadahnya, Jama ah yang ingin berubah menjadi baik, yang berkaitan dengan ibadah bisa dilihat dari perilaku jama`ah. Setelah mengikuti proses bimbingan agama jama`ah semakin rajin dalam mengikuti solat berjama`ah. Selain itu juga jam `ah setelah mengikuti bimbingan agama semakin termotivasi untuk membaca al-qur an setiap harinya; dan 3) semakin baik akhlaknya, Jama ah yang ingin berubah menjadi baik, yang berkaitan dengan akhlak bisa dilihat dari perilaku jama`ah. Setelah melakukan bimbingan agama, jama`ah dalam kehidupan sehari-hari menjadi lebih akrab dengan tetangga, lalu lebih sabar saat suami pergi dan bisa menjaga harta dari suami. 
Berdasarkan kesimpulan yang telah dikemukakan, maka penulis ingin menyampaikan saran, dalam mata kuliah teknik penyuluh agama lebih diperbanyak praktik dilapangan dibandingkan dengan teori yakni untuk melatih mahasiswa terampil dalam menyebar luaskan ilmu dakwah. Kemudian untuk peneliti selanjutnya hendaknya dapat mengkaji, mengeksplor dan menganalisis lebih dalam lagi terkait pelaksanaan bimbingan agama.

\section{DAFTAR PUSTAKA}

Amin, S.M. (2010). Bimbingan dan Konseling Islam. Jakarta: Amzah.

Arifin M. (1994). Pedoman Bimbingan dan Penyuluban Bimbingan Agama.Jakarta: PT Golden Terayon Press.

Arifin, I.Z. (2008). Bimbingan dan Konseling Islam (Al- Irsyad Wa Al-Tawjih Al-Islam) Berbasis Ilmu Dakwah. dalam Jurnal Ilmu Dakwah:Academic Journal For Homiletic Studies, 4, (11) 29.

Enjang, AS dan Mujib, A. (2013). Dasar-Dasar Bimbingan Dan Penyuluban Islam. Bandung: Sajjad Publishing House.

Inayah, I., Zanah, M., \& Tajiri, H. (2017). Bimbingan Keagamaan di Daerah

Pesisir dalam Irsyad: Jurnal Bimbingan, Penyuluban, Konseling, dan Psikoterapi Islam 5(1) 39-58

Kartono, K. (1997). Gangguan-Gangguan Psikis. Bandung: Sinar Baru.

Kusnawan, A, dkk., (2009). Dimensi Ilmu Dakwah. Bandung: Widya Padjadjaran.

Onong, U.F. (1993). Ilmu Teori dan Filsafat Komunikasi. Bandung: PT. Atra Aditya Bakti

Onong, U.F. (2004). Ilmu Komunikasi, Teori dan Praktek. Bandung: Remaja Rosdakarya.

Rakhmat, J. (2003). Psikologi Komunikasi. Bandung: Remaja Posda Karya.

Ruslan, I. (2014). Religiositas masyarakat pesisir : (Studi Atas Tradisi "Sedekah Laut" Masyarakat Kelurahan Kangkung Kecamatan Bumi Waras Kota Bandar Lampung) dalam Al-AdYaN 9(2) 63-88.

Satriah, L. (2015). Bimbingan Dan Konseling Islam. Bandung: Mimbar Pustaka. 